\title{
RET/TRIM24 Fusion Gene
}

National Cancer Institute

\section{Source}

National Cancer Institute. RET/TRIM24 Fusion Gene. NCI Thesaurus. Code C99852.

A fusion gene that results from a chromosomal translocation $t(7 ; 10)(q 34 ; q 11)$ which fuses the 5' portion of the RET gene and the 3' portion of the TRIM24 gene. This rearrangement is associated with papillary thyroid carcinoma. 